\title{
Effect of abomasal glucose infusion on alanine metabolism and urea production in sheep
}

\author{
T. Obitsu*†, D. Bremner, E. Milne and G. E. Lobley \\ Rowett Research Institute, Bucksburn, Aberdeen, Scotland, UK
}

(Received 11 May 1999 - Revised 17 December 1999 - Accepted 7 January 2000)

\begin{abstract}
The effect of abomasal infusion of glucose $\left(120 \mathrm{~kJ} / \mathrm{d}\right.$ per kg body weight $\left.(\mathrm{BW})^{0.75}, 758 \mathrm{mmol} / \mathrm{d}\right)$ on urea production, plasma alanine- $\mathrm{N}$ flux rate and the conversion of alanine- $\mathrm{N}$ to urea was studied in sheep offered a low-N diet at limited energy intake $\left(500 \mathrm{~kJ} / \mathrm{d}\right.$ per kg BW $\left.{ }^{0.75}\right)$, based on hay and grass pellets. Glucose provision reduced urinary $\mathrm{N}(P=0.040)$ and urea $(P=0.009)$ elimination but this was offset by poorer $\mathrm{N}$ digestibility. Urea-N production was significantly reduced $(822 v .619 \mathrm{mmol} / \mathrm{d}, P=0.024)$ by glucose while plasma alanine-N flux rate was elevated (295 v. $342 \mathrm{mmol} / \mathrm{d}, P=0 \cdot 011$ ). The quantity of urea-N derived from alanine tended to be decreased by glucose $(127 v .95 \mathrm{mmol} / \mathrm{d})$ but the fraction of urea production from alanine was unaltered $(15 \%)$. Plasma urea and alanine concentrations (plus those of the branched chain amino acids) decreased in response to exogenous glucose, an effect probably related to enhanced anabolic usage of amino acids and lowered urea production.
\end{abstract}

Glucose: Alanine: Ureagenesis: Gluconeogenesis: Sheep

In ruminants fed roughage, most of the dietary starch is fermented in the rumen and, in consequence, little or no glucose is available for absorption from the small intestine. When grain-based concentrate diets, which contain a greater fraction of less-fermentable starches are offered, glucose absorption from the small intestine is enhanced, as is the supply to the liver (Seal \& Reynolds, 1993). In both dietary situations, however, insufficient glucose is available from the diet to meet the needs of the animal. This shortfall is met by gluconeogenic sources, notably propionate, lactate and amino acids.

When exogenous glucose supply to ruminants is increased by infusion into the abomasum or the blood, then urinary $\mathrm{N}$ excretion is reduced and whole-body $\mathrm{N}$ retention increases (Eskeland et al. 1974; Matras \& Preston, 1989; Obitsu et al. 1993). This N-sparing effect of glucose may arise though several mechanisms. For example, hepatic gluconeogenesis may be inhibited if sufficient exogenous glucose is supplied (Judson \& Leng, 1973). Alternatively, the hyperglycaemiainduced hyperinsulinaemia may stimulate the uptake of amino acids into peripheral tissues (Brockman et al. 1975; Ahmed et al. 1983). Furthermore, glucose may inhibit the activity of the urea cycle (Jahoor \& Wolfe, 1987). Although any, or all, of these mechanisms may account for the improvement of $\mathrm{N}$ use with increased glucose supply, there are limited quantitative data on the fate of amino acid $\mathrm{N}$ in response to altered glucose supply. Of the amino acids extracted by the liver, alanine is the major gluconeogenic source (Wolff \& Bergman, 1972a; Reynolds \& Tyrell, 1991). Use of alanine-C to synthesise glucose releases the amino-N, which may be used to aminate oxo-acids or enter the ornithine cycle. These alternative fates have consequences for the availability of $\mathrm{N}$ for anabolic purposes. Furthermore, any reduction in requirement of amino acid-C for gluconeogenesis may be directed at essential amino acids, such as threonine (MacRae \& Egan, 1983), leaving alanine metabolism relatively unaffected. Alternatively, a general reduction in catabolism of all gluconeogenic amino acids may occur. Although the transfer of alanine- $\mathrm{C}$ across the liver in fed sheep has been studied with radioactive (Wolff \& Bergman, 1972a) and stable (Lobley et al. 1996) isotopes, the fate of the amino- $\mathrm{N}$ has not been elucidated clearly in ruminants.

In the current study, the fate of the ${ }^{15} \mathrm{~N}$-amino group of alanine to the urea production has been studied in response to abomasal infusion of glucose in sheep.

\section{Materials and methods}

\section{Animals}

Six Suffolk-cross wether sheep (average body weight (BW) 47 (SE 3.4) kg, 9-12 months of age) prepared with

\footnotetext{
Abbreviation: BW, body weight.

* Corresponding author: Dr T. Obitsu, fax +81 82422 7067, email tobitsu@ hiroshima-u.ac.jp

$\dagger$ Present address: Faculty of Applied Biological Science, Hiroshima University, 1-4-4 Kagamiyama, Higashihiroshima-shi 739-8528, Japan.
} 
an indwelling aortal catheter (Lobley et al. 1995) plus a polyvinyl chloride catheter in the abomasum were used. For infusion of labelled metabolites temporary polyvinyl chloride catheters $(0.8 \mathrm{~mm}$ i.d.; $1-2 \mathrm{~mm}$ o.d.; Critchley Electrical Products Pty. Ltd., Auburn, New South Wales, Australia) were inserted into each external jugular vein. One of these was inserted into the right ventricle of the heart to provide mixed systemic blood as a substitute if the arterial catheter failed.

\section{Experimental design}

Animals were maintained in metabolism crates and offered a mixed diet containing ryegrass pellets (estimated metabolizable energy $10.5 \mathrm{MJ} / \mathrm{kg} \mathrm{DM} ; 22.0 \mathrm{~g} \mathrm{~N} / \mathrm{kg} ; 893 \mathrm{~g} \mathrm{DM} / \mathrm{kg}$ ) and chopped hay (estimated metabolizable energy $9.2 \mathrm{MJ} /$ $\mathrm{kg} \mathrm{DM} ; 9.7 \mathrm{~g} \mathrm{~N} / \mathrm{kg} ; 945 \mathrm{~g} \mathrm{DM} / \mathrm{kg}$ ) in a ratio of $1: 1$, supplied as $24 \times 1 \mathrm{~h}$ portions by means of automated feeders. The daily amount of diet supplied $500 \mathrm{~kJ}$ metabolizable energy/d per $\mathrm{kg} \mathrm{BW}^{0.75}$ equivalent to approximately $1.25 \times$ maintenance energy requirement. Estimated metabolizable protein supply $\left(620 \mathrm{mg} \mathrm{N} / \mathrm{d}\right.$ per $\mathrm{kg} \mathrm{BW}^{0.75}$ ) was $15 \%$ lower than the energy provided, based on the need to support live-weight gain (Agricultural and Food Research Council, 1993). The experiment was conducted as a crossover design in which three sheep were started with a water infusion (control) followed immediately by glucose administration. The other three sheep were allotted to these treatments in reverse order. In each treatment, sheep were continuously infused with water or a glucose solution $\left(120 \mathrm{~kJ} / \mathrm{d}\right.$ per $\mathrm{kg} \mathrm{BW}^{0 \cdot 75}$; 137 (SE 8.0) g glucose/d) into the abomasum for $9 \mathrm{~d}$. The amount of glucose infused was adjusted to increase energy supply by $0 \cdot 3 \times$ maintenance energy per d. From days 6 to 9 , the animals were harnessed to allow total faeces (by bag) and urine (by suction from the rubber cup connected to the harness and set under the abdomen) to be collected for measurement of $\mathrm{N}$ balance and urinary urea excretion. From day 7 , a $\left[{ }^{14} \mathrm{C}\right]$ urea solution $(11 \mathrm{kBq} / \mathrm{g}$ dissolved in sterile $0.15 \mathrm{M}-\mathrm{NaCl}$ with $1 \mathrm{mM}$-urea as carrier) was infused into the jugular vein for $52 \mathrm{~h}$ at a rate of $44 \mathrm{kBq} / \mathrm{h}$. During the final $4 \mathrm{~h}$ of the $\left[{ }^{14} \mathrm{C}\right]$ urea infusion, urine was collected hourly to allow estimation of urea production rate. On day $9,\left[{ }^{15} \mathrm{~N}\right]$ alanine (99 atom \%; $40 \mathrm{mM}$ in sterile $0.15 \mathrm{M}-\mathrm{NaCl}$; Isotec Inc., Miamisburg, OH, USA) was infused into the jugular vein for $9 \mathrm{~h}$ at the rate of $0.4 \mathrm{mmol} / \mathrm{h}$. From $3 \mathrm{~h}$ after starting the $\left[{ }^{15} \mathrm{~N}\right]$ alanine infusion, arterial blood from the aorta (or mixed blood from the heart) was collected hourly. For $2 \mathrm{~d}$ before $\left[{ }^{15} \mathrm{~N}\right]$ alanine infusion, unlabelled alanine $(40 \mathrm{mM}$ in sterile $0 \cdot 15 \mathrm{M}-\mathrm{NaCl})$ was infused at the same rate to counteract any change of alanine flux as a consequence of the $\left[{ }^{15} \mathrm{~N}\right]$ alanine infusion. Immediately before each isotope infusion, the spot urine and blood samples were collected to determine the natural abundance of ${ }^{15} \mathrm{~N}$ (background).

\section{Sample preparation and chemical analyses}

A portion of total faeces was subsampled for each animal and freeze-dried. Urine for $\mathrm{N}$ balance was acidified with $\mathrm{H}_{2} \mathrm{SO}_{4}$ and the sub-samples were frozen $\left(-20^{\circ} \mathrm{C}\right)$ until later analysis. Plasma was separated from the hourly blood samples and frozen at $-20^{\circ} \mathrm{C}$ until later analysis.

DM contents of feed and faeces were measured after drying at $105^{\circ} \mathrm{C}$ for $4 \mathrm{~h}$. The $\mathrm{N}$ contents of the feed and faeces were determined following the Dumas method, using an automated procedure (Foss Haraeus Macro Nitrogen Analyser, York, UK). Urine N was quantified by a microKjeldahl procedure. The urea concentration in urine and plasma were measured on a Technicon Auto Analyser (Technicon Instruments Corporation, Tarrytown, NY, USA) by the method of Marsh et al. (1965). Plasma glucose concentration was determined by a glucose oxidase procedure on a Kone Dynamic Selective Analyser (Kone Instruments, Espoo, Finland). Free amino acid concentrations in plasma was measured by a LKB Alpha Plus Amino Acid Analyser (LKB Pharmacia, Uppsala, Sweden) using appropriate buffer combinations for physiological fluids. Specific radioactivity of urinary urea was determined as described previously (Lobley et al. 1996).

For the determination of plasma alanine and urea enrichment, stored plasma was deproteinized with $0 \cdot 15$ volumes sulfosalicylic acid (480 g/l) and centrifuged at $13000 \mathrm{~g}$ for $5 \mathrm{~min}$. The supernatant fraction was desalted by application to $2 \mathrm{ml}$ cation exchange resin (AG-50, 100-200 mesh, $\times 8$, $\mathrm{H}^{+}$form; Biorad, Richmond, CA, USA). After washing with $5 \mathrm{ml}$ water, urea was eluted with $30 \mathrm{ml}$ water (this recovers approximately $90 \%$ of the urea), followed by application of $3 \mathrm{ml} 4 \mathrm{M}-\mathrm{NH}_{4} \mathrm{OH}$ to collect the alanine. These two eluates were concentrated under reduced pressure and by freezedrying respectively. The freeze-dried alanine eluate was prepared as the tert-butyldimethylsilyl derivative (Calder \& Smith, 1988), the enrichment of which was determined by GC-mass spectrometry using a Trio 1 (VG Mass Lab., Manchester, UK).

Plasma urea enrichment was determined by GC-combustion-isotope ratio mass spectrometry (GC-C-IRMS). In order to improve the GC separation, urea was first converted to 2-hydroxypyrimidine (Wolthers et al. 1994). Samples were dried in v-vials to which $100 \mu \mathrm{l} 4 \mathrm{M}-\mathrm{HCl}$ and $50 \mu \mathrm{l}$ malondialdehyde bis-dimethylacetal (diluted $1: 20(\mathrm{v} / \mathrm{v})$ with water) were added and the reaction allowed to proceed at room temperature overnight. The reagent was then removed in a stream of $\mathrm{N}_{2}$ at room temperature before addition of $100 \mu \mathrm{l} N$-tert-butyldimethylsilyl- $N$-methyltrifluoracetamideacetonitrile $(1: 1, \mathrm{v} / \mathrm{v})$. The vials were heated in a dri-block at $100^{\circ} \mathrm{C}$ for $30 \mathrm{~min}$, leading to the formation of the tertbutyldimethylsilyl derivative of 2-hydroxypyrimidine. Of this $1 \mu \mathrm{l}$ (equivalent to approximately $30 \mathrm{nmol} \mathrm{N}$ ) was injected, in splitless mode, onto an HP 5890 gas chromatograph (Hewlett Packard, Avondale, PA, USA) connected to an ORCHID module (Europa Scientific, Crewe, Ches., UK). During passage though the ORCHID the sample is oxidised in a quartz tube containing platinised $\mathrm{Cu}$ wire, to produce $\mathrm{CO}_{2}, \mathrm{~N}_{2}$, nitrogen oxides and water. The nitrogen oxides were reduced to $\mathrm{N}_{2}$ in a second quartz tube containing $\mathrm{Cu}$ metal. $\mathrm{H}_{2} \mathrm{O}$ and $\mathrm{CO}_{2}$ were removed by a Nafion membrane (Perma Pure Inc., Toms River, NJ, USA) and a liquid $\mathrm{N}_{2}$ trap respectively. The resulting pure $\mathrm{N}_{2}$ gas was admitted to a SIRA Series II (VG Isotech, Middlewich, Ches., UK) mass spectrometer and ratio of $\mathrm{m} / \mathrm{z} 29 / 28$ measured against that in reference $\mathrm{O}_{2}$-free $\mathrm{N}_{2}$ gas. 


\section{Calculation and statistics}

Urea-N production rate (UNPR, $\mathrm{mmol} / \mathrm{d}$ ) was calculated from:

$$
\mathrm{UNPR}=\mathrm{I}_{\mathrm{u}} / \mathrm{SA}_{\mathrm{u}} \times 2 \times 1.44,
$$

where $I_{u}$ is the rate of $\left[{ }^{14} \mathrm{C}\right]$ urea infusion $(\mathrm{Bq} / \mathrm{min}) ; \mathrm{SA}_{\mathrm{u}}$ is the specific radioactivity of urinary urea $(\mathrm{Bq} / \mu \mathrm{mol}$ urea); 2 is the number of $\mathrm{N}$ in one urea molecule; and 1.44 is conversion factor of time scale. Urea-N entering the gastrointestinal tract was calculated as the difference between daily UNPR and the amount of urea-N eliminated in the urine. The appearance rate of plasma alanine (plasma alanine- $\mathrm{N}$ flux rate, $\mathrm{Ra}_{\text {ala }}, \mathrm{mmol} / \mathrm{d}$ ) was calculated from:

$$
\mathrm{Ra}_{\mathrm{ala}}=\left(\left(99 / \mathrm{E}_{\mathrm{ala}}\right)-1\right) \times \mathrm{I}_{\mathrm{ala}} \times 1.44,
$$

where $\mathrm{E}_{\mathrm{ala}}$ is the plasma alanine enrichment (atom \% excess) at pseudo-plateau; $\mathrm{I}_{\mathrm{ala}}$ is the rate of infusion $(\mu \mathrm{mol} / \mathrm{min}$ ) of $\left[{ }^{15} \mathrm{~N}\right]$ alanine; and 99 is the atom $\%$ of infused $\left[{ }^{15} \mathrm{~N}\right]$ alanine.

Because $\left[{ }^{15} \mathrm{~N}\right]$ urea enrichment did not reach isotopic steady state during the $9 \mathrm{~h}$ of the $\left[{ }^{15} \mathrm{~N}\right]$ alanine infusion, urea enrichment data were fitted by a non-linear regression according to a one-pool model (Model Maker, Cherwell Scientific Publishing Ltd, Oxford, Oxon., UK):

$$
\text { E-urea } \mathrm{t}_{\mathrm{t}}=\mathrm{A}\left(1-\mathrm{e}^{-\mathrm{kt}}\right) \text {, }
$$

where E-urea $a_{\mathrm{t}}$ is atom $\%$ excess ${ }^{15} \mathrm{~N}$ for plasma urea-N at time $\mathrm{t}$; $\mathrm{k}$ is the rate constant; and $\mathrm{A}$ is the ${ }^{15} \mathrm{~N}$ enrichment of urea-N at isotopic steady state.

The rate of transfer of alanine- $\mathrm{N}$ to urea $\mathrm{N}$ was calculated as follows:

$$
\text { urea-N derived from alanine-N }(\%)=\mathrm{A} / \mathrm{E}_{\mathrm{ala}} \times 100 ;
$$

and the rate of urea-N production from alanine- $\mathrm{N}(\mathrm{mmol} / \mathrm{d})$ $=\mathrm{UNPR} \times$ urea-N derived from alanine-N (\%). Because $\left[{ }^{15} \mathrm{~N}\right]$ alanine was infused for less than two half-lives of the body urea pool, there will be an uncertainty for the value obtained for the rate constant of urea-N-labelling $(\mathrm{k})$. This uncertainty will extend to the estimation for the plateau enrichment and subsequent calculations.

The results were analysed as a crossover design using the GLM procedure of SAS (SAS/STAT User's Guide (1995) version 6, 4th ed.; Statistical Analysis Systems Institute Inc., Cary, NC, USA) with animals as blocks and treatment and period as factors. If period effects were found to be not significant then the data were reanalysed with this factor excluded.

\section{Results}

Glucose infusion did not affect DM intake, except for one sheep that showed poor appetite during the period of $\left[{ }^{15} \mathrm{~N}\right]$ alanine infusion. Glucose infusion resulted in a slight increase in faecal DM output with a corresponding decrease in apparent DM digestibility $(P<0 \cdot 11$; Table 1$)$. As expected, plasma glucose concentration increased $(P<$ $0 \cdot 01$ ) with the glucose infusion (Table 1 ).

The glucose infusion did not affect $\mathrm{N}$ intake, but slightly increased $(P<0 \cdot 15)$ faecal $\mathrm{N}$ and reduced $(P<0 \cdot 10)$ digested $\mathrm{N}$ (Table 2$)$. In contrast, urinary $\mathrm{N}$ excretion was reduced $(P<0.05)$ by the glucose infusion. In consequence, $\mathrm{N}$ retention was unaltered.

Glucose infusion reduced both urea-N production rate $(P$ $<0.03)$ and plasma urea concentration $(P<0.05)$. Although there was also a decrease in the absolute amount of urea-N entering the gastrointestinal tract $(P=0 \cdot 1)$, the proportion of urea-N that entered the gastrointestinal tract was unaltered.

The plasma concentrations of aspartate, alanine, isoleucine and leucine decreased $(P<0.05)$ as a result of glucose infusion, with downward trends $(P<0 \cdot 1)$ also for valine and lysine (Table 3 ). In contrast, the concentrations of glycine increased $(P<0.05)$, while other amino acids were unaltered by treatment.

Plasma $\left[{ }^{15} \mathrm{~N}\right]$ alanine enrichments attained isotopic steady state for both treatments (Fig. 1(a)) and tended to be lower $(P<0 \cdot 15)$ for sheep infused with glucose (Table 4). Although $\mathrm{Ra}_{\text {ala }}$ increased $(P<0.05)$ with the glucose infusion, there was an associated period effect $(P<0 \cdot 05)$. The $\mathrm{Ra}_{\text {ala }}$ in sheep allotted to the control treatment first increased markedly with the glucose infusion (from 316 to $393 \mathrm{mmol} /$ d). Sheep infused with glucose first exhibited only a slight reduction (from 289 to $272 \mathrm{mmol} / \mathrm{d}$ ) during the control period.

Although plasma urea-N enrichment did not reach the isotopic steady state by the end of the blood sampling (Fig. 1(b)), there were no differences in the enrichments between the treatments at any time. Consequently, estimated urea-N enrichment at isotopic steady state, calculated by fitting the data to a one-compartment model, was only slightly lower during the glucose infusion. Glucose infusion tended to reduce the rate of alanine- $\mathrm{N}$ transfer to urea-N from 126 to $95 \mathrm{mmol} / \mathrm{d}$. Excluding the data of one sheep that had a poor appetite, the trend was shown more clearly $(P<0 \cdot 15)$. Although the proportion of urea-N derived from alanine-N

Table 1. Dry matter intake, faecal output and digestibility and plasma glucose concentration in sheep fed a ration of grass pellets plus hay, with or without abomasal infusion of glucose*

(Mean values for six sheep)

\begin{tabular}{lcccc}
\hline & & & \multicolumn{2}{c}{ ANOVAt } \\
\cline { 4 - 5 } Item & Control & Glucose-infused & SEM & $P$ \\
\hline Dry matter $(\mathrm{g} / \mathrm{d})$ & & & & \\
$\quad$ Intake $(\mathrm{g} / \mathrm{d})$ & 885 & 880 & 8.9 & $\mathrm{NS}$ \\
Faecal output $(\mathrm{g} / \mathrm{d})$ & 355 & 381 & 11.0 & $\mathrm{NS}$ \\
$\quad$ Digestibility $(\%)$ & 59.7 & 56.3 & 1.01 & 0.107 \\
Plasma glucose concentration $(\mathrm{mm})$ & 3.74 & 4.38 & 0.095 & 0.003 \\
\hline
\end{tabular}

${ }^{*}$ For details of procedures see p. 158.

†One-way ANOVA with sheep treated as blocks, 5 residual degrees of freedom. 
Table 2. Nitrogen balance $(\mathrm{g} / \mathrm{d})$ and urea-N production $(\mathrm{g} \mathrm{N} / \mathrm{d})$ in sheep fed a ration of grass pellets plus hay, with or without abomasal infusion of glucose*

(Mean values for six sheep)

\begin{tabular}{lcccc}
\hline & & & \multicolumn{2}{c}{ ANOVA } \\
\cline { 3 - 5 }$N$ transfer $(\mathrm{g} \mathrm{N} / \mathrm{d})$ & Control & Glucose-infused & SEM & $P$ \\
\hline Intake & 14.2 & 14.1 & 0.15 & $\mathrm{NS}$ \\
Faecal output & 6.3 & 7.1 & 0.30 & NS \\
Digested & 7.9 & 7.0 & 0.30 & 0.080 \\
Urinary excretion & & & & \\
$\quad$ Total N & 5.4 & 4.4 & 0.28 & 0.040 \\
Urea N & 3.0 & 2.0 & 0.18 & 0.009 \\
Retained & 2.4 & 2.6 & 0.30 & NS \\
Urea-N production & 11.5 & 8.8 & 0.57 & 0.024 \\
Urea-N recycled into the gut & 8.5 & 6.7 & 0.59 & 0.101 \\
$\quad \%$ of urea production & 73.6 & 77.4 & 1.90 & NS \\
Plasma urea (mM) & 2.20 & 1.66 & 0.152 & 0.041 \\
\hline
\end{tabular}

${ }^{*}$ For details of procedures see p. 158.

†One-way ANOVA with sheep treated as blocks, 5 residual degrees of freedom.

$(15 \%)$ was unaltered, there was a smaller proportion of plasma alanine-N flux $(28 v .42 \% ; P<0.06)$ transferred to urea-N when glucose was infused. This was partly a consequence of the higher plasma alanine-N flux during glucose infusion.

\section{Discussion}

The diet was formulated to minimise glucose absorption and, thus, glucose requirements for the sheep would need to be met by gluconeogenesis. Furthermore, the predicted fermentation and digestion would provide energy in excess relative to $\mathrm{N}$ supply (Agricultural and Food Research
Council, 1993). Therefore, any response to glucose provision should not be a consequence of an increase in energy availability but rather reflect direct aspects of glucose metabolism per se.

The amount of glucose infused which was absorbed from the small intestine was not quantified in the current study, but in cattle, $85 \%$ of glucose infused into the abomasum disappeared from the small intestine, with $73 \%$ of this recovered as net portal glucose flux (Kreikemeier \& Harmon, 1995). The increase in plasma glucose concentration observed with infusion in the present investigation probably reflects a similar increase in glucose absorption.

Table 3. Arterial plasma free-amino-acid concentrations $(\mu \mathrm{M})$ in sheep fed a ration of grass pellets plus hay, with or without abomasal infusion of glucose*

(Mean values for six sheep)

\begin{tabular}{lrrrr}
\hline & & & \multicolumn{2}{c}{ ANOVA } \\
\cline { 3 - 5 } Amino acids $(\mu \mathrm{M})$ & Control & Glucose-infused & SEM & $P$ \\
\hline Aspartate & 9.0 & 7.5 & 0.33 & 0.024 \\
Threonine & 100.2 & 80.1 & 9.96 & NS \\
Serine & 75.0 & 82.5 & 3.23 & NS \\
Asparagine & 71.5 & 69.4 & 3.21 & NS \\
Glutamate & 75.8 & 72.5 & 5.34 & NS \\
Glutamine & 295.6 & 272.2 & 12.47 & NS \\
Glycine & 489.1 & 571.3 & 23.97 & 0.043 \\
Alanine & 202.9 & 156.2 & 10.58 & 0.028 \\
Citrulline & 139.2 & 142.4 & 5.57 & NS \\
Valine & 229.3 & 185.9 & 10.98 & 0.078 \\
Methionine & 20.3 & 17.4 & 1.45 & NS \\
Isoleucine & 91.2 & 66.8 & 5.19 & 0.034 \\
Leucine & 119.8 & 94.2 & 5.25 & 0.031 \\
Tyrosine & 69.8 & 67.6 & 3.60 & NS \\
Phenylalanine & 54.5 & 53.4 & 1.68 & NS \\
Ornithine & 72.8 & 56.6 & 2.96 & 0.070 \\
Lysine & 109.7 & 75.7 & 8.40 & 0.052 \\
Histidine & 60.5 & 57.7 & 2.96 & NS \\
Tryptophan & 45.2 & 46.8 & 1.82 & NS \\
Arginine & 135.2 & 104.6 & 6.10 & NS \\
Total & 2643 & 2430 & 57.81 & NS \\
\hline
\end{tabular}

* For details of procedures see p. 158.

†One-way ANOVA with sheep treated as blocks, 5 residual degrees of freedom. 

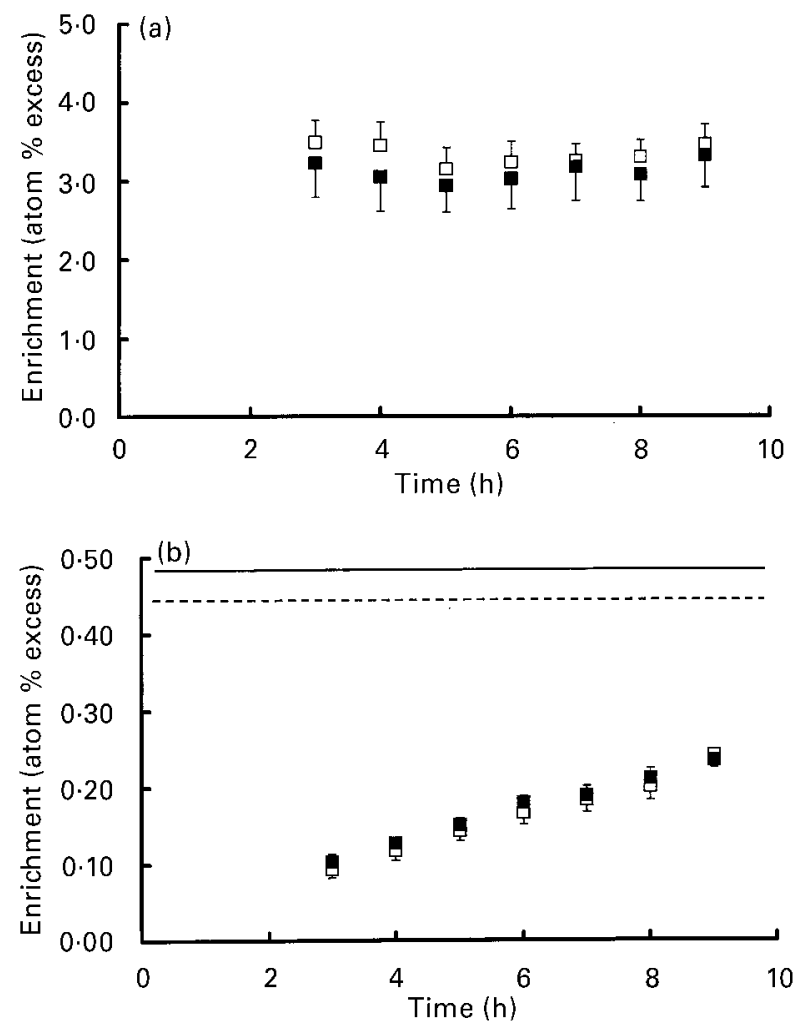

Fig. 1. Plasma enrichment of (a) $\left[{ }^{15} \mathrm{~N}\right]$ alanine and $(b)\left[{ }^{15} \mathrm{~N}\right]$ urea during infusion of $\left[{ }^{15} \mathrm{~N}\right]$ alanine into the jugular vein of sheep given ( $\square$ ), water (control) or ( $\mathbf{\square})$, glucose into the abomasum. Values are means for six lambs with standard errors indicated by vertical bars. (b): (-), plateau enrichment for the control, (- - - -), glucose infusion.

\section{Alanine metabolism}

Due to transamination reactions involving the amino-N, plasma alanine- $\mathrm{N}$ fluxes obtained in the present study may not equal the total flux of the C-skeleton. Comparisons of the fluxes obtained by the use of different labelled atoms would give some indication of the transamination of the amino-N. Plasma alanine-N fluxes obtained in the present study (control treatment, $205 \mu \mathrm{mol} / \mathrm{min} ; 11.8 \mu \mathrm{mol} / \mathrm{min}$ per $\mathrm{kg} \mathrm{BW}{ }^{0.75}$ ) were greater than for the plasma alanine-C flux observed in both adult $(192 \mu \mathrm{mol} / \mathrm{min}, 9.6 \mu \mathrm{mol} / \mathrm{min}$ per $\mathrm{kg} \mathrm{BW}{ }^{0.75}$; Wolff \& Bergman, 1972b) and young sheep $\left(142 \mu \mathrm{mol} / \mathrm{min} ; 9.7 \mu \mathrm{mol} / \mathrm{min}\right.$ per $\mathrm{kg} \mathrm{BW}^{0.75}$; Lobley et al. 1996a). These data suggest transamination exceeds C-skeleton flux by approximately 20-25\%. These calculations contrast with observations in post-absorptive human subjects, where alanine-N flux was lower than for alanine-C (Yang et al. 1984). The authors explained this apparent anomaly as conservation of the labelled amino-N through compartmentalized pyruvate-alanine interchange.

The increment of plasma alanine- $\mathrm{N}$ flux $(47 \mathrm{mmol} / \mathrm{d})$ by glucose infusion was equivalent to $6 \%$ of infused glucose $(760 \mathrm{mmol} / \mathrm{d})$ in the present study, although this value would be only $3 \%$ if supply of three $\mathrm{C}$ units was considered. This increase in plasma alanine-N flux by glucose infusion supports similar observations in human subjects (Robert et al. 1982; Wolfe et al. 1986). Reasons offered for these observations include: (1) an increase in alanine absorption; (2) stimulation of protein degradation in tissues; (3) enhanced alanine synthesis de novo. Short-term infusion of glucose into either the duodenum or blood of sheep fed dried grass led to increased net portal absorption of certain non-essential amino acids (Piccioli Cappelli et al. 1997), notably citrulline, glycine and ornithine, but not alanine. In other studies with sheep fed a diet of cereal and straw, net portal absorption of amino acids decreased as a result of glucose infusion into the jugular vein (Balcells et al. 1995). In human subjects, intravenous glucose infusion increased alanine-N flux though stimulation of alanine synthesis de novo, with protein breakdown unaltered (Robert et al. 1982). Thus, the increase in the alanine-N flux with glucose infusion in the present study was probably due to an increase in alanine synthesis.

Plasma alanine concentration was reduced with abomasal glucose infusion, in spite of the increase in the wholebody alanine flux. Similar reductions were noted for the branched-chain amino acids. These may be caused by insulin-mediated mechanisms because intraduodenal or intravenous infusion of glucose stimulates insulin secretion

Table 4. $\left[{ }^{15} \mathrm{~N}\right]$ Alanine flux and urea kinetics in sheep fed a ration of grass pellets plus hay, with or without abomasal infusion of glucose $(758 \mathrm{mmol} / \mathrm{d})^{*}$

(Mean value for six sheep)

\begin{tabular}{|c|c|c|c|c|}
\hline \multirow[b]{2}{*}{ Item } & \multirow[b]{2}{*}{ Control } & \multirow[b]{2}{*}{ Glucose-infused } & \multicolumn{2}{|c|}{ ANOVA† } \\
\hline & & & SEM & $P$ \\
\hline \multicolumn{5}{|l|}{ Alanine kinetics } \\
\hline Plateau enrichment (ape) & $3 \cdot 3$ & 3.0 & $0 \cdot 11$ & NS \\
\hline Plasma alanine- $\mathrm{N}$ flux $(\mathrm{mmol} / \mathrm{d})$ & 295 & 342 & $7 \cdot 3$ & $0.033 \ddagger$ \\
\hline \multicolumn{5}{|l|}{ Urea-N kinetics } \\
\hline Production rate $(\mathrm{mmol} / \mathrm{d})$ & 820 & 619 & $40 \cdot 9$ & 0.024 \\
\hline Predicted plateau enrichment (A; ape) & 0.485 & 0.444 & 0.0218 & NS \\
\hline Rate constant of urea-N labelling $(\mathrm{k} ; \% / \mathrm{h})$ & $7 \cdot 13$ & 8.92 & 0.0218 & NS \\
\hline Urea-N production derived from alanine- $\mathrm{N}(\mathrm{mmol} / \mathrm{d})$ & 126 & 95 & $14 \cdot 2$ & NS \\
\hline$\%$ of total urea-N production & $15 \cdot 1$ & $15 \cdot 4$ & 1.41 & NS \\
\hline$\%$ of plasma alanine- $\mathrm{N}$ flux & $42 \cdot 2$ & $27 \cdot 6$ & $3 \cdot 14$ & 0.059 \\
\hline
\end{tabular}

ape, atom percent excess.

* For details of procedures see pp. 158-159.

† One-way ANOVA with sheep treated as blocks, 5 residual degrees of freedom.

$\ddagger$ Period effect was observed $(P=0.046)$. 
in a dose-dependent manner in ruminants (Balcells et al. 1995; Piccioli Cappelli et al. 1997). Elevation of plasma insulin concentration by intravenous infusion of the hormone lowered plasma amino acid concentrations but increased amino acid uptake to peripheral tissues (Brockman et al. 1975; Ahmed et al. 1983). This stimulation of the peripheral uptake of amino acids may reduce the hepatic inflow of amino acids for urea synthesis.

\section{Urea synthesis}

In the present study, the increase in glucose supply $(136 \mathrm{~g} / \mathrm{d}$, $760 \mathrm{mmol} / \mathrm{d}$ ) though the abomasal infusion reduced urea-N production by $200 \mathrm{mmol} / \mathrm{d}$. Because short-term intraduodenal infusion of glucose did not decrease $\mathrm{NH}_{3}$ absorption from the portal-drained viscera (Piccioli Cappelli et al. 1997) and hepatic extraction of $\mathrm{NH}_{3}$ has a higher priority than amino acid removal (Lobley \& Milano, 1997), the reduced ureagenesis probably reflects lower amino acid catabolism.

An increase in exogenous glucose supply reduced the apparent endogenous glucose production from gluconeogenic precursors, other than ruminal propionate (Judson \& Leng, 1972). Thus, gluconeogenesis from alanine is probably also reduced with glucose infusion. Consequently, it would be expected that $\mathrm{N}$ transfer from alanine to urea would be reduced correspondingly.

To test this hypothesis, the $\mathrm{N}$ transfer from alanine to urea was predicted from the ${ }^{15} \mathrm{~N}$ enrichment of plasma alanine and urea after the intrajugular infusion of $\left[{ }^{15} \mathrm{~N}\right]$ alanine. Based on the results of Judson \& Leng (1973), the increase in glucose supply through the abomasal infusion in this study $(136 \mathrm{~g} / \mathrm{d})$ should reduce endogenous glucose production by $36 \mathrm{~g} / \mathrm{d}(200 \mathrm{mmol} / \mathrm{d})$. Assuming that $5.4 \%$ of glucose C was derived from alanine (Wolff \& Bergman, 1972a), then this reduction in gluconeogenesis could spare alanine by $10 \mathrm{mmol} / \mathrm{d}$. A similar reduction in alanine amino-N transfer to urea would be expected. In the present study, however, the glucose infusion reduced alanine- $\mathrm{N}$ transfer to urea by a much greater extent $(30 \mathrm{mmol} / \mathrm{d})$.

The proportional contribution of alanine-N to urea-N (15\%) did not appear to be affected by the glucose infusion in the present study, although this contribution was higher than that based on calculations of net hepatic movements of alanine and urea- $\mathrm{N}$ in sheep fed a similar level of roughage (6.9\%, Lobley et al. 1995). $\mathrm{NH}_{3}$ may contribute $59-72 \%$ of urea-N in sheep fed similar rations (Lobley et al. $1995,1996 b, 1998)$ and thus a maximum of $28-41 \%$ would arise from amino acid-N. Under these circumstances alanine would make a disproportionately large contribution to ureagenesis (36-54\%) compared to other amino acids. This would suggest that a substantial portion of the alanine extracted by the liver is destined for 'catabolic' fates, oxidation, gluconeogenesis and ureagenesis, rather than 'anabolic' end products, synthesis of constitutive and export proteins. An alternative explanation for the large contribution of alanine- $\mathrm{N}$ to urea- $\mathrm{N}$ is that entry of alanine- $\mathrm{N}$ into the ornithine cycle (via aspartate) is more indirect and involves transamination reactions with other amino acids. In this case, the transfer of ${ }^{15} \mathrm{~N}$ in alanine to urea may represent gross rather than net $\mathrm{N}$ movements.
If it is assumed that exogenous glucose provision did not alter hepatic extraction of $\mathrm{NH}_{3}$ (Lobley \& Milano, 1997) then the decrease in non- $\mathrm{NH}_{3}-\mathrm{N}$ inflow into the ornithine cycle was quite substantial (probably $>48 \%$ ). If this were due solely to a reduced need for precursor $\mathrm{C}$ for glucose synthesis then disproportionate reductions in metabolism of those amino acids known to be gluconeogenic in sheep, i.e. alanine, glutamate, glutamine, glycine, serine (Wolff \& Bergman, 1972a) and threonine (MacRae \& Egan, 1983) might be expected. This did not occur for alanine in that the fractional contribution to urea- $\mathrm{N}$ synthesis remained unaltered. One possible reason is that 'sparing' occurred for the other amino acids, but the linkage between alanine and glucose is maintained, as observed in non-ruminants where the two metabolites are involved in $\mathrm{C}$ and $\mathrm{N}$ transfers between the liver and peripheral tissues (Perriello et al. 1995). Alternatively, the decrease in urea-N entering the gastrointestinal tract and the slight increase in faecal-N output with glucose infusion may reduce the absorption and hepatic removal of $\mathrm{NH}_{3}$ as well as amino acids. However, short-term glucose supply did not affect net portal absorption of $\mathrm{NH}_{3}$ (Piccioli Cappelli et al. 1997). Thus, the reduction in urea-N recycling may be another reason for the unaltered contribution of alanine- $\mathrm{N}$ to urea-N with glucose infusion.

In conclusion, glucose infusion into the abomasum caused a reduction of urea synthesis and urinary excretion in sheep. This depression in urea synthesis was accompanied by a trend for smaller absolute transfer of alanine-N to urea. Thus, increases in glucose absorption from the small intestine may contribute to an increase in flow of amino acids to peripheral tissues and reduce the wastage as urinary $\mathrm{N}$ excretion.

\section{Acknowledgements}

The authors gratefully acknowledge the expert technical input of Miss Maureen Annand for the assay of urea and glucose, Messrs D.S. Brown for the amino acid analysis and A.G. Calder for the measurement of alanine enrichment. T. Obitsu was supported by the Japan Society for the Promotion of Science. This work was funded as part of the core budget to the Rowett Research Institute from the Scottish Office Agriculture, Environment and Fisheries Department.

\section{References}

Agricultural and Food Research Council (1993) Energy and Protein Requirements of Ruminants. Wallingford: CAB International.

Ahmed BM, Bergen WG \& Ames AK (1983) Effect of nutritional state and insulin on hind-limb amino acid metabolism in steers. Journal of Nutrition 113, 1529-1543.

Balcells J, Seal CJ \& Parker DS (1995) Effect of intravenous glucose infusion on metabolism of portal-drained viscera in sheep fed a cereal/straw-based diet. Journal of Animal Science 73, 2146-2155.

Brockman RP, Bergman EN, Joo PK \& Manns JG (1975) Effects of glucagon and insulin on net hepatic metabolism of glucose precursors in sheep. American Journal of Physiology 229, 1344-1350.

Calder AG \& Smith A (1988) Stable isotope ratio analysis of 
leucine and ketoisocaproic acid in blood plasma by gas chromatography/mass spectrometry. Use of tertiary butyldimethylsilyl derivatives. Rapid Communications in Mass Spectrometry 2 , 14-16.

Eskeland B, Pfander WH \& Preston RL (1974) Intravenous energy infusion in lambs: effects on nitrogen retention, plasma free amino acids and plasma urea nitrogen. British Journal of Nutrition 31, 201-211.

Jahoor F \& Wolfe RR (1987) Regulation of urea production by glucose infusion in vivo. American Journal of Physiology 253, E543-E550.

Judson G \& Leng RA (1973) Studies on the control of gluconeogenesis in sheep: effect of glucose infusion. British Journal of Nutrition 29, 159-174.

Kreikemeier KK \& Harmon DL (1995) Abomasal glucose, maize starch and maize dextrin infusions in cattle: small-intestinal disappearance, net portal glucose flux and ileal oligosaccharide flow. British Journal of Nutrition 73, 763-772.

Lobley GE, Bremner D, Nieto R, Obitsu T, Hotston Moore A \& Brown DS (1998) Transfers of N-metabolites across the ovine liver in response to short-term infusions of an amino acid mixture into the mesenteric vein. British Journal of Nutrition 80, 371-379.

Lobley GE, Connell A, Lomax MA, Brown DS, Milne E, Calder AG \& Farningham DAH (1995) Hepatic detoxification of ammonia in the ovine liver: possible consequences for amino acid catabolism. British Journal of Nutrition 73, 667-685.

Lobley GE, Connell A, Revell DK, Bequette BJ, Brown DS \& Calder AG (1996a) Splanchnic-bed transfers of amino acids in sheep blood and plasma, as monitored through use of a multiple $\mathrm{U}-{ }^{13} \mathrm{C}$-labelled amino acid mixture. British Journal of Nutrition 75, 217-235.

Lobley GE \& Milano GD (1997) Regulation of hepatic nitrogen metabolism in ruminants. Proceedings of the Nutrition Society 56, 547-563.

Lobley GE, Weijs PJM, Connell A, Calder AG, Brown DS \& Milne E (1996b) The fate of absorbed and exogenous ammonia as influenced by forage or forage-concentrate diets in growing sheep. British Journal of Nutrition 76, 231-248.

MacRae JC \& Egan AR (1983) Threonine catabolism and gluconeogenesis in pregnant ewes. British Journal of Nutrition 49, 385-393.

Marsh WH, Fingerhut B \& Miller H (1965) Automated and manual direct methods for determination of blood urea. Clinical Chemistry 2, 624-627.

Matras J \& Preston RL (1989) The role of glucose infusion on the metabolism of nitrogen in ruminants. Journal of Animal Science 67, 1642-1647.
Obitsu T, Taniguchi K \& Yamatani Y (1993) Utilization of energy and nitrogen in early weaned calves nourished by intragastric infusion: effects of the proportion of volatile fatty acids infused into the rumen, with abomasal infusion of glucose and casein. Animal Science and Technology (Japan) 64, 692-699.

Patterson BW, Carraro F \& Wolfe RR (1993) Measurement of ${ }^{15} \mathrm{~N}$ enrichment of multiple amino acids and urea in a single analysis by gas chomatography/mass spectrometry. Biological Mass Spectrometry 22, 518-523.

Perriello G, Jorde R, Nurjhan N, Stumvoll M, Dailey G, Jenssen T, Bier DM \& Gerich JE (1995) Estimation of glucose-alaninelactate-glutamine cycles in post-absorptive humans - role of skeletal muscle. American Journal of Physiology 32, E443E450.

Piccioli Cappelli F, Seal CJ \& Parker DS (1997) Glucose and $\left[{ }^{13} \mathrm{C}\right]$ leucine metabolism by the portal-drained viscera of sheep fed on dried grass with acute intravenous and intraduodenal infusions of glucose. British Journal of Nutrition 78, 931-946.

Reynolds CK \& Tyrell HF (1991) Effects of mesenteric vein L-alanine infusion on liver metabolism in beef heifers fed on diets differing in forage: concentrate ratio. British Journal of Nutrition 66, 437-450.

Robert JJ, Bier DM, Zhao XH, Matthews DE \& Young VR (1982) Glucose and insulin effects on de novo amino acid synthesis in young men: studies with stable isotope labelled alanine, glycine, leucine and lysine. Metabolism 31, 1210-1218.

Seal CJ \& Reynolds CK (1993) Nutritional implication of gastrointestinal and liver metabolism in ruminants. Nutrition Research Reviews 6, 185-208.

Wolff JE \& Bergman EN (1972a) Glucogenesis from plasma amino acids in fed sheep. American Journal of Physiology 223, 455-460.

Wolff JE \& Bergman EN (1972b) Metabolism and interconversion of five plasma amino acids by tissues of the fed sheep. American Journal of Physiology 223, 447-454.

Wolfe RR, Shaw JHF, Jahoor F, Herdon DN \& Wolfe MH (1986) Response to glucose infusion in humans: role of change in insulin concentration. American Journal of Physiology 250, E306-E311.

Wolthers BG, Tepper T, Withag A, Nagel GT, de Haan, THY, van Leeuwen JJ, Stegemen CA \& Huisman RM (1994) GC-MS determination of ratios of stable-isotope labelled to natural urea using $\left[{ }^{13} \mathrm{C}^{15} \mathrm{~N}_{2}\right]$ urea for studying urea kinetics in serum and as a means to validate routine methods for the quantitative assay of urea in dialysate. Clinica Chimica Acta 225, 29-42.

Yang RD, Matthews DE, Bier DM, Lo C \& Young VR (1984) Alanine kinetics in humans: influence of different isotopic tracers. American Journal of Physiology 247, E634-E638. 